\title{
Supercritical water oxidation of toxic waste generated in veterinary practices
}

\begin{abstract}
The preservation of anatomical samples is a critical step in the veterinary practices. For this purpose, formaldehyde diluted in water is commonly used. It is deposited in large ponds where the pieces are placed. The problem is that in Colombia this chemical is considered as a pollutant by the environmental forensic authorities, due its properties and the damage that it can be caused to the water resources if it is no treated before to disposal. To treat this waste and prevent legal problems it was selected the supercritical oxidation technique. This method is highly efficient in destruction of toxic organic compounds. The samples were obtained from the Anatomical Lab of La Salle University in Bogotá-Colombia. The best result was an efficiency of destruction of $99.51 \%$ using $500^{\circ} \mathrm{C}, 5 \mathrm{~min}$ and $100 \% \mathrm{H}_{2} \mathrm{O}_{2}$ Excess. It permitted the reduction of COD from $9200 \mathrm{mg} \mathrm{L}-1$ to $40 \mathrm{mg} \mathrm{L}-1$, allowing the compliance of the regulation and indicating that the method is effective for the treatment of this kind of waste in a batch reactor.
\end{abstract}

Keywords: formaldehyde, supercritical water oxidation SCWO, anatomical labs waste
Volume 6 Issue 3 - 2018

\author{
Rosalina González, Paula Cárdenas, Andrea \\ Landinez \\ Department of Environmental and Sanitary Engineering, La Salle \\ University, Colombia
}

Correspondence: Rosalina Gonzalez, La Salle University, Environmental Engineering Program, Postal Code I I0821052 42I, Bogotá, Colombia, Tel 57300534 8575, Fax + 5 I I 3 414169, Email rogonzalez@unisalle.edu.co

Received: April 23, 2018 | Published: May 16, 2018
Abbreviations: SCWO, Supercritical water oxidation; COD, chemical oxygen demand

\section{Introduction}

Fixation is a crucial step in the veterinary practices that involve preservation procedures to anatomical pieces to prevent decomposition. Fixation helps to preserve cellular architecture and composition of cells in the tissue to allow them to withstand subsequent processing. Fixation also preserves the proteins, carbohydrate and other bio-ac moieties in their spatial relationship to the cell, so that they can be studied. ${ }^{1}$ Formaldehyde has been the most commonly fixative substance used to prevent decomposition of anatomical pieces and is used in addition as fungicide, germicide, and industrial disinfectant, making it a pollutant of sanitary interest, due to its solubility y in water, generating high risk for water resources. ${ }^{2}$ The environmental forensic authorities must check that this chemical has not dump into the sewer system of this kind as conventional waste without prior treatment. To prevent legal problems this research, propose SCWO, that is a process developed for organic waste destruction and especially for aqueous waste streams, sludges, and hazardous or high-risk wastes such as chemical warfare agents. ${ }^{3}$ The process takes advantage of the unique properties of water above its thermodynamic critical point $\left(374^{\circ} \mathrm{C}, 221 \mathrm{bar}\right) .^{4}$ It exhibits favorable qualities for carrying out oxidation reactions in environments that other techniques as conventional treatments no have had success. This occurs because the hydrogen bridges disappear and water behaves like an organic solvent. ${ }^{5}$ At the same time, the oxygen solubility increases, making the organic compounds completely miscible. In supercritical conditions the oxidation reaction is complete. Most toxic organic compounds can be rapidly oxidized to $\mathrm{CO}_{2}$ and $\mathrm{H}_{2} \mathrm{O}$ in a very short residence time in supercritical water. ${ }^{6}$ The supercritical method was selected because some researchers have been found that when the water reaches a supercritical condition of temperature and pressure it exhibits favorable qualities for carrying out oxidation reactions in environments that other techniques as conventional treatments no have had success. This unconventional technique has proved to be effective for destroying highly stable persistent organic pollutants in wastewaters that cannot be treated in a cost-effective manner by conventional technologies. ${ }^{7}$

\section{Methods}

\section{Reagents}

a. Hydrogen peroxide $50 \%$

b. Formaldehyde $37 \%$

\section{Sampling}

It was performed an appropriate sampling used the method described in the IDEAM manual (Environmental Authority in Colombia). In-situ parameters such as temperature, $\mathrm{pH}$ and solids were measured and then the sample was kept in a refrigerator. Subsequently the sample was transported to the laboratories of Environmental Engineering at La Salle University in Bogota, where analysis of $\mathrm{COD}$, fats and oils, TSS and $\mathrm{pH}$ for identifying the composition of the sample were performed.

\section{Design and construction of the reactor}

The construction of the reactor was carried out with a high-pressure tubing $1 / 4$ " $(0.635 \mathrm{~cm})$ external diameter and a thickness of 0.035 " $(0.0889 \mathrm{~cm})$ Swagelok brand. This type of pipe and the design of two elastic splints dampens temperature changes occurring during starting and stopping of the trial, it helps eliminate leakage related to thermal expansion and contraction. ${ }^{8}$ To assemble the reactor a segment of 34 $\mathrm{cm}$ was cut to insert it into the muffle, and then was sealed reactor with a set of nuts and ferrules on each end, following the directions of assembly provided by the brand used, placing the nut into the tube, then the two braces, which are manually adjusted to the maximum.

Then, using the press was set the male screw and nut with a wrench with $3 / 4$ back is adjusted (Figure 1 ). ${ }^{8}$ 


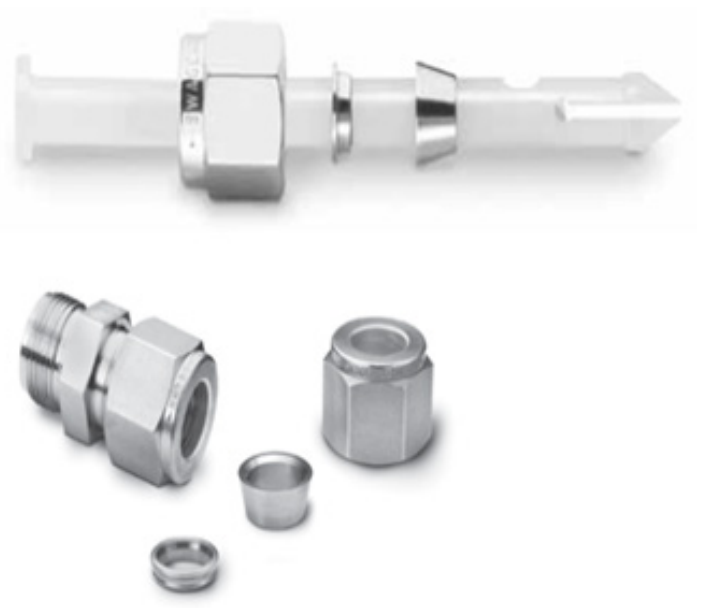

Figure I Caps and splints.

\section{Experimental design}

The experimental methodology was $2 \mathrm{k}$ factorial design in which the temperature (A), percent excess oxidant (B) and the time (C) are handled as variables, to study how these three affect the reaction. Because $\mathrm{k}$ is the number variable to evaluate the experimental methodology, it was run a factorial design $2^{\wedge} 3$. Eight tests were conducted, each of them with a replica, additionally three levels were used: high, middle and low studied, which resulted in 20 tests with the results obtained in each test an analysis of variance, with which the influence of each of the variables in the treatment took place was determined. ${ }^{8}$ The range of variables, were established from the literature review on supercritical oxidation technique. Temperature between $400^{\circ} \mathrm{C}$ and $500^{\circ} \mathrm{C}$. Oxidation time between 5 and 20 minutes, Excess hydrogen peroxide between 100\% - 300\%. Experimental domain of a continuous factor expressed with the minimum and maximum values that can take, and the coded notation to the lower level -1 and +1 was assigned to the upper (- and + for simplicity). ${ }^{9}$ To determine the volume to be injected into the reactor was taken into account the available volume within it, the excess percentage of peroxide oxygen, fluid density to the experimental temperatures were determined through open access program "Chemicalogic steam tab". Taking as volume injected $0.76 \mathrm{~mL}, 0.93 \mathrm{~mL}$ and $1.41 \mathrm{~mL}$, at temperatures of $500^{\circ} \mathrm{C}, 450^{\circ} \mathrm{C}$ and $400^{\circ} \mathrm{C}$ respectively. Additionally, the composition of the mixture between the sample and the oxidant varies depending on the percentage of excess and the fluid density in supercritical temperature (Table 1) (Table 2).

Table I Dimensions and reactor design

\begin{tabular}{ll}
\hline Inside diameter Din= Dext- $\left(2^{*}\right.$ espesor $)$ & \\
Dext $(\mathrm{cm})$ & 0.635 \\
Thickness $(\mathrm{cm})$ & 0.035 \\
Din $(\mathrm{cm})$ & 0.565 \\
\hline Cross Area $A=((\Pi($ Dint $) \wedge 2) / 4$ & \\
\hline Din $(\mathrm{cm})$ & 0.565 \\
Cross Area $\left(\mathrm{cm}^{2}\right)$ & 0.251 \\
\hline Reactor volume V=A*L & \\
\hline Cross Area $\left(\mathrm{cm}^{2}\right)$ & 0.251 \\
Length $(\mathrm{cm})$ & 34 \\
Total volume of the reactor to normal conditions $\left(\mathrm{cm}^{3}\right)$ & 8.5 \\
\hline
\end{tabular}

Table 2 Sample and oxidant volumes to be injected

\begin{tabular}{|c|c|c|c|}
\hline Initial DQO (mg/L) 9200 & & & \\
\hline $\begin{array}{l}\text { Test } \\
\text { Calculation basis } 0.005 \mathrm{~L}\end{array}$ & $400^{\circ} \mathrm{C}$ & $450^{\circ} \mathrm{C}$ & $500^{\circ} \mathrm{C}$ \\
\hline \multicolumn{4}{|l|}{$300 \% \mathrm{H}_{2} \mathrm{O}_{2}$ Excess } \\
\hline Samle sln & 0.78 & & \\
\hline \% Sample & 86.48 & & \\
\hline$\% \mathrm{H}_{2} \mathrm{O}_{2}$ & 13.52 & & \\
\hline Sample to inject (ml) & 1.22 & 0.8 & 0.65 \\
\hline $\mathrm{H}_{2} \mathrm{O}_{2}$ to inject $(\mathrm{ml})$ & 0.19 & 0.13 & 0.1 \\
\hline \multicolumn{4}{|l|}{$200 \% \mathrm{H}_{2} \mathrm{O}_{2}$ Excess } \\
\hline Samle sln & 0.59 & & \\
\hline \% Sample & 89.5 & & \\
\hline$\% \mathrm{H}_{2} \mathrm{O}_{2}$ & 10.5 & & \\
\hline Sample to inject (ml) & 1.26 & 0.83 & 0.68 \\
\hline $\mathrm{H}_{2} \mathrm{O}_{2}$ to inject $(\mathrm{ml})$ & 0.15 & 0.1 & 0.08 \\
\hline \multicolumn{4}{|l|}{$100 \% \mathrm{H}_{2} \mathrm{O}_{2}$ Excess } \\
\hline Samle sln & 0.39 & & \\
\hline \% Sample & 92.75 & & \\
\hline$\% \mathrm{H}_{2} \mathrm{O}_{2}$ & 7.25 & & \\
\hline Sample to inject $\mathrm{ml}$ ) & 1.31 & 0.86 & 0.7 \\
\hline $\mathrm{H}_{2} \mathrm{O}_{2}$ to inject $(\mathrm{ml})$ & 0.1 & 0.07 & 0.05 \\
\hline
\end{tabular}

\section{Experimental analysis}

Several preliminary tests were conducted to establish the variable values to use; for that purpose, a synthetic sample was made and was carried to supercritical conditions with reaction time in the range of 5 to 30 minutes, temperature variation between 300 to $500^{\circ} \mathrm{C}$ and oxidizing agent from $100 \%$ to $300 \%$ of excess. Once the ranges of the variables were found, 16 experimental tests were made a sweepstakes in order to determine the order of trials and ensure their representativeness and randomness (Table 3 ), and were made the same procedure described in the preliminary tests. With the ranges established for experimentation it was determined that the experimental tests included a temperature variation between 400 to $500^{\circ} \mathrm{C}$, Reaction Times in the range of 5 to 20 minutes and Hydrogen Peroxide $\left(\mathrm{H}_{2} \mathrm{O}_{2}\right)$ was selected as an oxidizing agent from 100 to $300 \%$ of excess of the stoichiometric reaction of destruction of formaldehyde. For tests, the solution to be injected was prepared corresponding to each of the trials using micropipettes $100 \mu \mathrm{l}$ and $1000 \mu \mathrm{L}$ for introducing the fluid into the reactor. The same experimental procedure was conducted for both preliminary tests and experimental. The source providing the proper temperature for each test was a muffle furnace in which the reactor was introduced with the corresponding security measures, which were characterized by the use of forceps, gloves bait and Industrial mask. The reactor should be within the stove while carrying out the test, in order to ensure the reaction time (Figure 2). Upon completion of the time required for the test the reactor is removed with rapier and is necessary to cool it, for this reason the reactor placed on a piece of wood for about 15 minutes to avoid thermal shock and damage of the ferrules of the reactor.

Then, the reactor was cooled with water from the center to their splints to extend the useful life of this. Finally, with the help of the press and a wrench we proceed to unscrew the game splints one end 
of the reactor to collect the sample in a test tube with micropipettes. After each test, should be noted the importance of cleaning the reactor prior to the completion of each test in order to avoid cross contamination. ${ }^{10}$ Tracking the removal efficiency was measured by means of COD (chemical oxygen demand) in the Hach equipment. The analytical method for the determination of COD is the method 8000 which handles ranges between $3-170 \mathrm{mg} / \mathrm{L}$ and 20 to $1500 \mathrm{mg} / \mathrm{L} .{ }^{11}$

Table 3 Test experimental results
For COD determination of tests dilutions were made with deionized water of each sample in order to obtain the volume required for the COD parameter which corresponds to $2 \mathrm{ml}$. With the results of the experimental test the appropriate analysis of variance in order to determine the most important variables in the process was conducted, and whether the supercritical oxidation is an efficient technique for the treatment of liquid waste generated in veterinary practices. ${ }^{9}$

\begin{tabular}{|c|c|c|c|c|c|c|c|c|c|c|}
\hline \multirow{2}{*}{ Testing } & \multirow{2}{*}{ Label } & \multirow{2}{*}{$\begin{array}{l}\mathrm{T}^{\circ} \mathrm{C} \\
\text { (A) }\end{array}$} & \multirow{2}{*}{$\begin{array}{l}t \text { min } \\
\text { (B) }\end{array}$} & \multirow{2}{*}{$\% \mathbf{H}_{2} \mathbf{O}_{2}(\mathbf{C})$} & \multirow{2}{*}{ Initial COD mg/L } & \multicolumn{2}{|c|}{ Final COD mg/L } & \multicolumn{2}{|c|}{ Conversion \% } & \multirow{2}{*}{$\begin{array}{l}\text { Average } \\
\%\end{array}$} \\
\hline & & & & & & Test & Duplicate & Test & Duplicate & \\
\hline I & 1 & 400 & 5 & 100 & 8532 & 156 & 283 & 98.17 & 96.88 & 97.53 \\
\hline 2 & a & 500 & 5 & 100 & 8532 & 40 & 44 & 99.53 & 99.48 & 99.51 \\
\hline 3 & $b$ & 400 & 20 & 100 & 8532 & 52 & 20 & 99.39 & 99.77 & 99.58 \\
\hline 4 & $a b$ & 500 & 20 & 100 & 8532 & 106.7 & 110 & 98.75 & 98.71 & 98.73 \\
\hline 5 & c & 400 & 5 & 300 & 7955 & 76 & 86 & 99.04 & 98.92 & 98.98 \\
\hline 6 & ac & 500 & 5 & 300 & 7955 & 84 & 50 & 98.94 & 99.37 & 99.16 \\
\hline 7 & bc & 400 & 20 & 300 & 7955 & 76 & 76 & 99.04 & 99.04 & 99.04 \\
\hline 8 & $a b c$ & 500 & 20 & 300 & 7955 & 16 & 155 & 99.8 & 98.05 & 98.93 \\
\hline
\end{tabular}

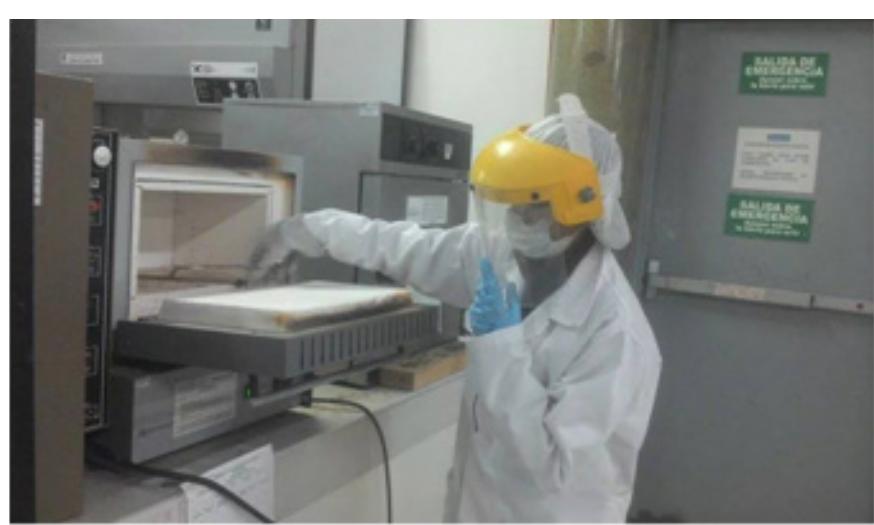

Figure 2 Experimental test.

\section{Results and discussion}

The results of eight experimental trials with the respective duplicates are described below, each assay is determined based on Table 4. The initial COD of $9200 \mathrm{mg} \mathrm{L}-1$ and the best final COD of $40 \mathrm{mg}$.L-1 of the anatomy lab sample. The percentage conversion is by decreasing the concentration of COD. The COD of each test varies depending on the mixture of the oxidizing agent and the sample. Regarding the results in the experimental tests (Table 2), A and B tests were the best with 99.51 and $99.58 \%$ removal efficiency respectively indicating that the method is effective for the treatment of this kind of waste in a batch reactor. However, the best conditions for carrying out the test is $500^{\circ} \mathrm{C}, 5 \mathrm{~min}$ and $100 \% \mathrm{H}_{2} \mathrm{O}_{2}$, Excess in the test Figure $3 \mathrm{~A}$ because even though the temperature of $400^{\circ} \mathrm{C}$ represents a lower energy cost, it must be held for 20 minutes, while temperatures over $500^{\circ} \mathrm{C}$ requires 5 minutes only (The higher the temperature, the lower the required time, and the lower the temperature, the higher the time required). The analysis of each variable used in the study indicates that that the temperatures used in the study are equally efficient to degrade the chemical, because the differences are small between them. Figure $3 \mathrm{~B}$ shows that the best conversions are in 5 and $20 \mathrm{~min}$; indicating that the minimum time used can be selected as the time to remove the contaminant. $\mathrm{B}$, and $\% \mathrm{H}_{2} \mathrm{O}_{2}$ in Figure $3 \mathrm{C}$ indicates that the minimum excess of oxidant is convenient to make the removal of formaldehyde. However, this analysis must be completed with a $2 \times 2 \times 2$ Analysis of Variance, results of this analysis are in the tables below (Table 5-9): These results show that the interaction between Time and Temperature are the most significant relationship in the removal of formaldehyde because this interaction is the only one with $\mathrm{P}$ less than 0.05 and $\mathrm{F}$ is difference than the other values. As is observed in the table the tree variable interaction tends to be significant in addition to A and B.

Table 4 Experimental Variables

\begin{tabular}{|c|c|c|c|}
\hline Variable & High (+I) & Low (-I) & Medium (o) \\
\hline Temperature $\left({ }^{\circ} \mathrm{C}\right)$ & 500 & 400 & 450 \\
\hline Time (min) & 20 & 5 & 12 \\
\hline $\mathrm{H}_{2} \mathrm{O}_{2}$ Excess (\%) & 300 & 100 & 200 \\
\hline
\end{tabular}

Table 5 Data entry

\begin{tabular}{|c|c|c|c|c|c|}
\hline \multicolumn{6}{|c|}{ Data Entry } \\
\hline & Al & & & A2 & \\
\hline & $\mathrm{Cl}$ & $\mathrm{C} 2$ & & $\mathrm{Cl}$ & $\mathrm{C} 2$ \\
\hline \multirow[t]{2}{*}{ B I } & 98.17 & 99.04 & \multirow{2}{*}{ B I } & 99.53 & 98.94 \\
\hline & 96.88 & 98.92 & & 99.48 & 99.37 \\
\hline \multirow[t]{2}{*}{ B2 } & 99.39 & 99.04 & \multirow{2}{*}{ B2 } & 98.75 & 99.8 \\
\hline & 99.77 & 99.04 & & 98.71 & 98.05 \\
\hline
\end{tabular}




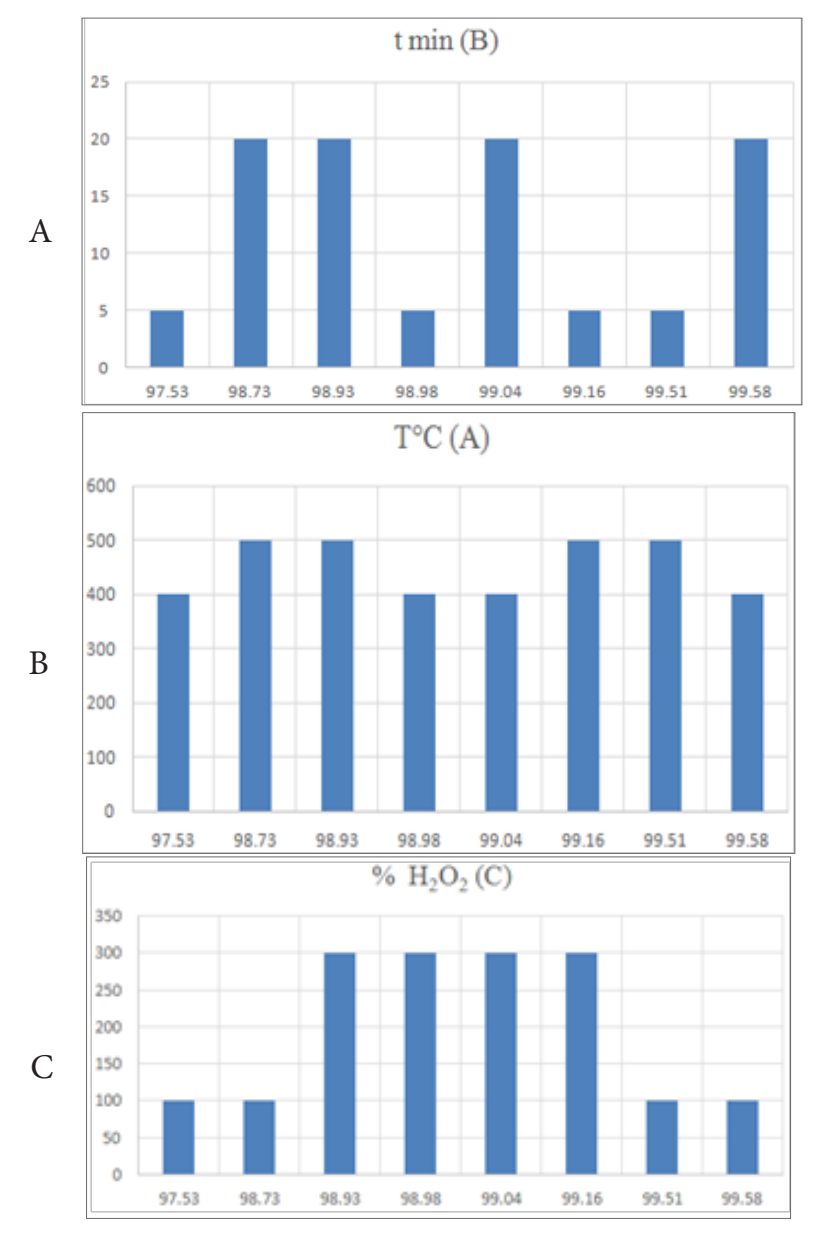

Figure 3 Relation between Conversion \% and the variables used in the study (A) Temperature $\left({ }^{\circ} \mathrm{C}\right),(B)$ time $(\mathrm{min}),(\mathrm{C}) \% \mathrm{H}_{2} \mathrm{O}_{2}$.

Table 6 Values of NABC

\begin{tabular}{|c|c|c|c|c|c|}
\hline \multicolumn{6}{|c|}{ Values of N ABC } \\
\hline \multicolumn{3}{|c|}{ Al } & \multicolumn{3}{|c|}{ A2 } \\
\hline & $\mathrm{Cl}$ & $\mathrm{C2}$ & & $\mathrm{Cl}$ & C2 \\
\hline B I & 2 & 2 & B I & 2 & 2 \\
\hline \multirow[t]{8}{*}{ B2 } & 2 & 2 & B2 & 2 & 2 \\
\hline & & Al & 8 & & \\
\hline & & $\mathbf{A 2}$ & 8 & & \\
\hline & & B I & 8 & & \\
\hline & & B2 & 8 & & \\
\hline & & Cl & 8 & & \\
\hline & & C2 & 8 & & \\
\hline & & Total & 16 & & \\
\hline
\end{tabular}

Table 7 Mean values $A B C$

\begin{tabular}{llllll}
\hline \multicolumn{3}{l}{ Mean Values ABC } & & \\
\hline \multicolumn{3}{c}{ A1 } & & & A2 \\
& CI & C2 & & C1 & C2 \\
BI & 97.53 & 98.98 & B1 & 99.505 & 99.155 \\
B2 & 99.58 & 99.94 & B2 & 98.73 & 98.925 \\
\hline
\end{tabular}

Table 8 Values of AB-AC-BC

\begin{tabular}{llll}
\hline AB & & & \\
\hline & AI & A2 & \\
BI & 98.22 & 99.33 & 98.7912 \\
B2 & 99.31 & 98.8275 & 99.0688 \\
& 98.78 & 99.0787 & 98.93 \\
AC & & & \\
& A1 & A2 & \\
BI & 98.55 & 99.1175 & 98.835 \\
B2 & 99.01 & 99.04 & 99.025 \\
& 98.78 & 99.0787 & 98.93 \\
BC & & & \\
& A1 & A2 & \\
B1 & 98.52 & 99.155 & 98.835 \\
B2 & 99.07 & 98.9825 & 99.025 \\
& 98.79 & 99.0688 & 98.93
\end{tabular}

Table 9 ANOVA summary

\begin{tabular}{llllll}
\hline \multicolumn{7}{l}{ ANOVA Summary } \\
\hline Source & SS & df & MS & F & P \\
\hline A & 0.35 & I & 0.35 & 1.09 & 0.32699 \\
B & 0.31 & I & 0.31 & 0.97 & 0.353526 \\
C & 0.14 & I & 0.14 & 0.44 & 0.52577 I \\
AB & 2.43 & I & 2.43 & 7.59 & 0.024866 \\
AC & 0.29 & II & 0.29 & 0.91 & 0.368045 \\
BC & 0.53 & I & 0.53 & 1.66 & 0.233614 \\
ABC & 1.61 & I & 1.61 & 5.03 & 0.055187 \\
Error & 2.54 & 8 & 0.32 & & \\
Total & 8.2 & 15 & & & \\
\hline
\end{tabular}

\section{Conclusion}

Regarding the best result in the experimental tests was " $\mathrm{A}$ " test with $99.51 \%$ removal efficiency indicating that the method is effective for the treatment of this kind of waste in a batch reactor. The best conditions for carrying out the test is $500^{\circ} \mathrm{C}, 5 \mathrm{~min}$ and $100 \%$ $\mathrm{H}_{2} \mathrm{O}_{2}$ Excess. 


\section{Acknowledgements}

The present study was funded by the vice chancellor office of research and development of La Salle University. We are grateful to the Professor Victor Marulanda and Environmental Engineer Paola Marulanda. Most importantly, none of this would have been possible without the love and patience of our family. Also my research project was fully sponsored by La Salle University with grant number CIV1PI-24326713.

\section{Conflict of interest}

We have the Journal's policy, and the authors of the study certify that there is no conflict of interest.

\section{References}

1. Thavarajah R, Mudimbaimannar VK, Elizabeth J, et al. Chemical and physical basics of routine formaldehyde fixation. $J$ Oral Maxillofac Pathol. 2012;16(3):400-405.

2. Formaldehyde and Cancer Risk .USA. National Cancer Institute; 2012.

3. Barner H, Huang C, Johnson T, et al. Supercritical water oxidation: an emerging technology. J Hazardous Mat. 1992;31(1):1-17.
4. Weingartner H, Franck EU. Supercritical water as a solvent. Angewandte Chemie Int. 2005;44(18):2672-2692.

5. Brock EE, Savage PE, Barker JR. A reduced mechanism for methanol oxidation in supercritical water. Chem Eng Sci. 1998;53(5): 857-867.

6. Martino CJ, Savage PE. Thermal decomposition of substituted phenols in supercritical water. Industrial \& engineering chemistry research. 1997;36(5):1385-1390.

7. Marulanda V, Bolaños G. Supercritical water oxidation of a heavily PCB-contaminated mineral transformer oil: Laboratory-scale data and economic assessment. J of Supercritical Fluids. 2010;54(2):258-265.

8. Gaugeable Tube Fittings and Adapter Fittings. Swagelok. 2015; 1-69.

9. Montgomery D. Desing and analysis of experiments. Universidad estatal de Arizona Seguna Edicion Editorial Limusa Wiley. 2005; 1-26.

10. Moreno S, Torres C. Aplicacion de la tecnologia de oxidación en agua supercrírtica al tratamiento de aguas residuales de la industria de las curtiembres. Tesis de grado Universidad de la Salle. 2012.

11. Oxygen Demand. Hach Company \& Hach Lange GmbH: USA; 2004. 